\title{
A Multisectoral Approach to Advance Health Equity in Northern Arizona: County-level Leaders' Perspectives on Health Equity
}

Dulce J. Jiménez ( $\square$ dulce.jimenez@nau.edu )

Northern Arizona University, Center for Health Equity Research https://orcid.org/0000-0003-2962-7467

\section{Samantha Sabo}

Northern Arizona University, Center for Health Equity Research

Mark Remiker

Northern Arizona University, Center for Health Equity Research

Melinda Smith

Northern Arizona University, Center for Health Equity Research

Alexandra E. Samarron Longorio

Northern Arizona University, Center for Health Equity Research

Heather J. Williamson

Northern Arizona University, Center for Health Equity Research

Carmenlita Chief

Northern Arizona University, Center for Health Equity Research

Nicolette I. Teufel-Shone

Northern Arizona University, Center for Health Equity Research

\section{Research Article}

Keywords: health equity, multisector, collective impact, community health

Posted Date: March 9th, 2022

DOI: https://doi.org/10.21203/rs.3.rs-1048269/v2

License: (c) (i) This work is licensed under a Creative Commons Attribution 4.0 International License.

Read Full License 


\section{Abstract}

Background: Multisectoral and public-private partnerships are critical in building the necessary infrastructure, policy, and political will to ameliorate health inequity. By focusing on health equity, researchers, practitioners, and decision-makers make explicit the systematic, avoidable, unfair, and unjust differences in health status across population groups sustained over time and generations, beyond the control of individuals. Health equity requires a collective process in shaping the health and wellbeing of the communities in which we live, learn, work, play, move, and grow.

Methods: Data are drawn from the Southwest Health Equity Research Collaborative's Regional Health Equity Survey (RHES). The RHES is a community-informed, cross-sectional online survey comprised of 31 quantitative and 17 qualitative questions. Generated to elicit an interdisciplinary body of knowledge and guide future multisectoral action for improving community health and well-being, the RHES targeted leaders representing five large rural northern Arizona counties and 13 distinct sectors. To explore, multisectoral leaders' knowledge, attitudes, and actions to address the social, environmental, and economic conditions that produce and sustain health inequity were analyzed using a priori coding scheme and emergent coding with thematic analysis.

Results: Although leaders were provided the definition and asked to describe the root causes of inequities, the majority of leaders described social determinants of health $(\mathrm{SDOH})$. When leaders described root causes of health inequity, they articulated systemic factors affecting their communities and described discrimination and unequal allocation of power and resources. Most leaders described the SDoH of their communities by discussing compounding factors of poverty, transportation, and housing among others, that together exacerbate inequity. Leaders also identified specific strategies to address SDoH and advance health equity in their communities, ranging from providing direct services, to activating partnerships across organizations and sectors in advocacy for policy change.

Conclusion: Our findings indicate that community leaders in the northern Arizona region acknowledge the importance of multisectoral partnerships and collaborations in improving health equity for the populations that they serve. However, a common understanding of health equity remains to be widely established, which is essential for conducting effective multisectoral work with the goal of advancing health equity.

\section{Introduction}

Over the last decade, public health researchers and practitioners have shifted their focus from identifying health disparities to addressing the economic, social and environmental 'root causes' of health inequity $(1,2)$. This shift was motivated by the recognition of significant differences in the burden of disease in communities of color and change required in tackling the larger patterns of social inequalities that produce health inequities. To address this fundamental issue, the social determinants of health (SDoH) framework has emerged to define how the conditions in which people are born, grow, live, and work (3) 
contribute to sickness and wellness. While an important contribution to public health, the SDoH framework does not explicitly address the underlying social and institutional inequities largely based on class, race, disability-status, citizenship, and gender. That is to say, unlike an equity lens, a SDoH framework does not offer a critical analysis of the inequitable distribution of power and resources, and the institutional policies and practices that influence opportunities to be healthy. Health equity offers a framework of knowledge and practice rooted in a commitment to reducing and ultimately eliminating health disparities and addressing the $\operatorname{SDoH}(4,5)$. The shift in lexicon, principles, and practice from health disparities, to the SDoH and finally to an intentional commitment to health equity, signals a paradigm shift rooted in a critical understanding of justice, fairness, and power structures. (citation) While health equity frameworks are more common within the public health and health care sectors, other sectors critical to advancing health equity, such as housing, economic development, transportation, education, and justice, among many others, have yet to be engaged.

Collaboration between diverse sectors, public, private, and/or grassroots organizations, with a shared goal of achieving health equity can be defined as a multisectoral approach to health equity (6). This type of approach was highlighted in the seminal 2017 National Academies of Sciences, Engineering, and Medicine Communities in Action: Pathways to Health Equity (3), which described community-driven health equity projects that involved two or more sectors and emphasized the "pathways" in which diverse sectors, such as civil rights, business, education, and transportation could promote health equity through programming and policy (3). A multisectoral approach involves bringing people from different sectors together to strategize around a common goal. Multisectoral health equity approaches comes with challenges, for example, aligning interests of different stakeholders (7), developing multisectoral partnerships that are sustainable (7-10), and the time required for relationship building (8). Despite these challenges, a multisectoral approach is identified as an effective means to address health inequities, align public health priorities across sectors and with the community, and improve the efficiency of public health efforts $(6,8,11-13)$. However, lack of a common language and clarity around the concept of health equity remains a barrier to forming and sustaining multisectoral partnerships with the goal of advancing health equity $(14,15)$. Without a shared understanding of health equity, partners from different sectors may struggle to participate in important conversations, develop policy and practice goals, and allocate resources to address health inequities $(14,15)$.

To explore this issue in sectors across northern Arizona, a geographically expansive, largely rural culturally diverse region, this paper documents leaders' representing various sectors beyond public health and health care, understanding of the SDoH and their strategies to address health inequities both locally and regionally.

\section{Methods}

Data area drawn from the Community Engagement Core (CEC) of Northern Arizona University's Southwest Health Equity Research Collaborative (SHERC), a National Institute of Health (NIH) National Institute of Minority Health and Health Disparities (NIMHD) funded Research Centers in Minority 
Institutions. The CEC is guided by asset-based, community-engaged frameworks that recognize health as a product of multiple social determinants and health inequities driven by poverty, structural racism, ableism, misogyny, and discrimination in which community-based solutions are necessary, but not sufficient to achieve health equity $(3,16)$.

Beginning in 2018, the SHERC CEC engaged county-level leaders from various sectors to identify drivers of health inequity and identify local assets nurturing multisectoral approaches to addressing the root causes of inequity in the region. The CEC developed the 2019 Regional Health Equity Survey (RHES), a cross-sectional online survey designed to explore how leaders and decision-makers understand and describe health inequity and strategize to address health inequities in their communities (for the complete survey, see supplementary file, Regional Health Equity Survey-Data Collection Instrument). The survey was administered to leaders in five counties and 13 sectors in northern Arizona. Survey development and outcomes are described in detail in Remiker (2021) (17). The RHES's development was guided by a regional, multisectoral community advisory council (CAC) that assisted in design and administration. The 11-member CAC was composed of leaders across northern Arizona, representing diverse sectors, including for example, early childhood development, education, criminal justice, public health, and policy. CAC members also represented the vast geographic expanse (more than 6,000 square miles of land) and cultural diversity including 12 federally recognized American Indian tribes, and five largely rural counties (18).

\section{Regional Health Equity Survey (RHES)}

The CEC engaged members of the CAC - personally, professionally, and geographically diverse leaders in northern Arizona - to generate specific survey constructs important to achieving, maintaining, and scaling health equity in the region. Additionally, the RHES is adapted from the Bay Area Regional Health Inequities Initiative's (BARHII) Organizational Self-Assessment for Addressing Health Inequities Toolkit (19), which helps public health leaders identify the skills, organizational practices, and infrastructure needed to take action in addressing health equity. CAC members and SHERC project staff engaged in two rounds of edits and through a process of consensus finalized the RHES, comprised of 48 questions, including 17 open-ended questions. Constructs include the distribution of resources in the communities served, personal understanding of social determinants of health, organizational capacity to address health inequities, extent and focus of cross-sectoral partnerships, use of data in decision making, the role of research in addressing health inequities in the community, and priority areas for future research. A set of closed and open-ended questions were used to characterize multisectoral leaders' understanding of the following: (1) the primary community they serve, including how resources are distributed within the community; (2) the SDoH and the root causes of health inequity; and (3) strategies to address health equity locally and regionally.

\section{Participants}

The population surveyed by the RHES included community, organizational, and grassroots leaders from five northern Arizona counties, representative of the following sectors: 1) community health and 
economic development; 2) health and human services; 3) law, justice, and public safety; 4) parks and recreation; 5) policy; 6) early childhood development; 7) transportation; 8) food systems; 9) housing; 10) education; 11) arts, music, and culture; 12) planning and zoning; and 13) cultural resources management. An internet search was conducted to identify potential participants. All potential participant names were compiled, duplicate names were removed, and county-level participant lists were generated for each sector. Two to three county champions per county (e.g., assistant county manager and local public health director) vetted each county's list, removing names of individuals no longer in their positions and filling in gaps in sectors where representation was absent. Once participant lists were finalized, introductory emails were sent by county champions alerting all potential participants to the survey administration plans. Invitations to participate in the RHES, including links to the survey, were circulated electronically by CEC staff one day after introductory e-mails were sent. Participants received two reminder e-mails 2 and 4 weeks after the initial invitation. All respondents were offered a $\$ 25$ gift card as compensation for their participation. The RHES was distributed via e-mail using an online survey software (Qualtrics XM, Provo, UT). The RHES was reviewed and approved by the Northern Arizona University Institutional Review Board (project number: 1198096-1). Detailed methods used to develop and implement the RHES are described in Remiker (2021) (17).

\section{Analysis}

All descriptive statistics were analyzed using IBM Statistical Package for Social Sciences software (version 26). Considering the differences in types of responses from each open-ended question, qualitative data were analyzed using either a priori coding or emergent coding and a thematic analysis approach in ATLAS.ti 8 (ATLAS.ti Scientific Software Development GmbH, Berlin, Germany).

To analyze the open-ended question exploring SDoH and root causes, BARHII definitions were used as an initial a priori broad coding scheme to understand when participants were discussing SDoH versus root causes of health inequity (Table 1). The Vitalyst Health Foundation's Elements of a Healthy Community (20) were then applied to the a priori codebook to include specific SDoH. To capture the full range of SDoH described by participants, codes that emerged from the data were also added to the a priori codebook. The full data set was independently coded by one researcher. Then, a second researcher independently coded $25 \%$ of the responses. The two researchers reviewed their independent coding together until consensus on codes and themes was achieved through intensive discussion. As a final step, the full data set was reviewed and revised for accurate coding by the first researcher based on the consensus decisions (21).

Remaining open-ended question (i.e., strategies to address health equity), were analyzed using emergent coding, where one researcher read through all the responses, summarized broad themes, and shared findings with a second researcher. During a collective review of participants' summarized responses, codes and more specific themes that emerged from the data were discussed and agreed upon. The first researcher then applied the refined codes to the data and, together with the second researcher, achieved consensus on final themes. 
Table 1

Regional Health Equity Survey Thematic Code Definitions (19)

\section{Broad Code Definition}

$\begin{array}{ll}\text { Health } & \text { Health inequities are the systematic, avoidable, unfair, and unjust differences in health } \\ \text { Inequity } & \text { status across population groups. These inequities are sustained overtime and } \\ \text { generations and are beyond the control of individuals. These differences follow the } & \text { larger patterns of inequality that exist in society. This is different from the term health } \\ \text { disparities, which emphasizes that differences exist, but does not consider their } \\ \text { relationship patterns of social inequalities. The term health inequities will be used } \\ \text { throughout this survey. }\end{array}$

Root The root causes of health inequity are the underlying social, economic, and

Causes of environmental inequalities which create different living conditions. Discrimination Health based on class, race, ethnicity, immigration status, gender, sexual orientation, Inequity disability and other 'isms' influence the distribution of resources and power. Past discriminatory practices are reinforced in the policies and practices of institutions that define the context of our daily lives. This in turn creates an unequal distribution of beneficial opportunities and negative exposures, resulting in health inequities.

Social Determinant of Health (SDoH)
The social determinants of health are the conditions in which people are born, grow, live, work and age (e.g. air quality, schools, parks, jobs, and housing conditions etc.). This term does not address how or why these social, economic, and environmental conditions are inequitably distributed throughout society.

\section{Results}

A total of 206 of the 560 invited multisectoral representatives (response rate $37 \%$ ) from northern Arizona participated in the RHES. Of those who participated, 64\% (132/206) completed the entire survey, responding to the open-ended qualitative questions of interest about: (1) the root causes of health inequity that impact the health of the community they serve, and (2) strategies to address health equity. Among those that answered open-ended questions, half held government positions at the federal, state, county, and municipality level and one-third worked for non-government organizations, including community-based organizations, community groups or coalitions, faith-based organizations, and nonprofits. Participants reported holding leadership positions such as county managers and department directors, chief of police, superintendents, presidents, CEOs, and executive directors. The demographic breakdown of all survey participants did not significantly differ for those that provided qualitative responses. Therefore, Table 2 provides participant demographics for the entire survey reflective of qualitative respondents.

Participants were primarily middle aged, predominantly white leaders, with slightly more female participations compared to male. Leaders were well established within their sectors with an average of 16 years in the field and stable in their positions with an average of 5 years in their current leadership role. All participants held leadership positions and largely reported they did not work directly with the community within their current role. 
Table 2

Participant Demographics

\begin{tabular}{|c|c|}
\hline Demographic Characteristic & $\begin{array}{l}\text { Total Participants } \\
\text { N (\%) }\end{array}$ \\
\hline Gender & $\mathrm{N}=129$ \\
\hline Male & $56(43.4)$ \\
\hline Female & $69(53.5)$ \\
\hline Other & $1(0.8)$ \\
\hline Prefer not to answer & $3(2.3)$ \\
\hline Race and Ethnicity & $\mathrm{N}=129$ \\
\hline American Indian/Alaskan Native & $3(2.3)$ \\
\hline Asian/Pacific Islander & $1(0.8)$ \\
\hline Black/African American & $3(2.3)$ \\
\hline Hispanic/Latino & $6(4.7)$ \\
\hline White & $108(83.7)$ \\
\hline Other & $3(2.3)$ \\
\hline Prefer not to answer & $5(3.9)$ \\
\hline Age in years & $\mathrm{N}=127$ \\
\hline Mean (SD) & $49(11.6)$ \\
\hline Position time in months & $\mathrm{N}=195$ \\
\hline Mean (SD) & $5.3(6.0)$ \\
\hline Sector time in months & $N=194$ \\
\hline Mean (SD) & $16.6(11.1)$ \\
\hline County & $\mathrm{N}=\mathbf{2 0 6}$ \\
\hline Apache & $8(3.9)$ \\
\hline Coconino & $94(45.6)$ \\
\hline Mohave & $34(16.5)$ \\
\hline Navajo & $28(13.6)$ \\
\hline Yavapai & $42(20.4)$ \\
\hline Organization & $\mathrm{N}=204$ \\
\hline
\end{tabular}




\begin{tabular}{|ll|}
\hline Demographic Characteristic & $\begin{array}{l}\text { Total Participants } \\
\text { N (\%) }\end{array}$ \\
\hline Government & $102(49.5)$ \\
\hline Non-government & $57(27.7)$ \\
\hline Private & $11(5.3)$ \\
\hline Academic & $20(9.7)$ \\
\hline Other & $14(6.8)$ \\
\hline Work Directly with Community Constituents & $\mathbf{N}=192$ \\
\hline Yes & $37(19.3)$ \\
\hline No & $155(80.7)$ \\
\hline
\end{tabular}

Participants could identify with more than one sector. While all 13 sectors were represented, $95 \%$ of all participants identified with either health and human services (49\%), education (26\%), or community and economic development (20\%) (Figure 1).

\section{Community Demographics}

Two questions elicited characteristics of the communities served, including survey questions regarding leaders' perceived understanding of the distribution of resources and services within the community they serve and an open-ended question asking respondents to describe the root causes of health inequity.

Upwards of $75 \%$ of participants reported resources and services to unevenly or inequitably distributed across all sectors in the communities they serve (Figure 2). According to one quarter of survey participants, resources and services related to public safety and children's education were perceived to be the most evenly or equitably distributed resources in the community.

\section{Multisectoral Leaders Perceptions of Health Inequity}

Participants were provided the definitions of the SDoH and root causes of health inequity outlined in Table 1 and asked to describe the root causes of health inequity in their community. Approximately $64 \%$ $(n=132)$ of participants responded to this question, and of those respondents, $11.4 \%(n=15)$ provided a description that met the a priori definition of root causes of health inequity. The remaining participants provided an explanation that met the a priori definition of a SDoH and, in certain instances, leaders discussed other factors outside of the definitions applied for health inequity and SDoH. Exemplary quotes below are followed by the participant's self-identified position and sector.

Root Causes of Health Inequity 
When leaders described root causes of inequity, they articulated systemic factors affecting the communities they serve and primarily described discrimination and unequal allocation of power and resources.

Some of the participants discussed the role discrimination plays in health and economic inequities in their communities. A few mentioned the type of discrimination, for example based on race, sex, or class. Often, participants discussed discrimination and racism at both institutional and systemic levels and included perspective on the deleterious effects on past and current policies perceived to be discriminatory, as articulated here:

"The root cause of health inequity is racism, systemic and institutional racism." [Program manager, health and human services]

"The primary social conditions that impact the (housing and homeless) community I serve seem to be systemic racism and systemic poverty, which are, of course, inextricably related." [Owner and research scientist, multisector]

"Many unincorporated townships passing laws stating the outright ban of "box stores" and other affordable/accessible services. Past policies around land distribution and land use disproportionately impacting Native communities. Infrastructure, or lack thereof, favoring higher income brackets and more able-bodied peoples: lack of sidewalks, elevators, handicap access, specialized services, etc. Classism affecting poor families, and especially families of color with childcare and early education opportunities being too expensive for most to afford. Free or reduced-price options fill up quickly with wait times being years long." [Senior program coordinator, multisector]

Some participants described unequal allocation of power and resources. Most leaders who identified this phenomenon as a root cause of health inequity in their community gave robust explanations, providing examples of how this unequal allocation manifests as a complex interlocking of systems of power. Many leaders went on to describe how this contributes to inequity across $\mathrm{SDoH}$ and place specific communities, especially communities of color and people living in poverty, at a direct disadvantage. A regional director that identified as multisectoral and serves families with young children and higher risk populations identified root causes of health inequity and resulting effects as:

The root cause here is the same as it is anywhere - unequal distribution of money, opportunity and power. How that shows up in my community is: Essential services provided in population hubs where cost of living is too high for those who most need services. Virtually no public transportation, wage disparity, lack of entry level employment opportunities, social and geographic isolation, technology vacuums outside of population hubs - although about $95 \%$ of the population owns a smart phone, data services for their use is too expensive, or there is spotty/no service in many of the outlying rural areas. Very limited affordable housing. The most "affordable" housing is the furthest from services/food/socialization. Yavapai (county) has been identified as a mental health desert. Yavapai (county) has been identified as a food 
desert. Limited access to quality medical specialists. Not enough medical providers. Very limited services for families with children with special needs.

Social Determinants of Health

Approximately $75 \%$ of responses were categorized by the a priori definition of an SDoH. Guided by the SDoH specific code definition, we further categorized the types of SDoH leaders perceived as impacting the health of the community they serve. Based on these SDoH definitions, the predominate SDoH described by multisectoral leaders included community design, environmental quality, social justice, housing, social/cultural cohesion, economic opportunity, quality affordable food, community safety, transportation, educational opportunity, access to care, and health equity. These themes are summarized in Table 3 in order of frequency. [Insert Table 3 below] 
Table 3

Description of Themes for Social Determinants of Health Codes in Order of Frequency

\begin{tabular}{|c|c|c|}
\hline Code & Theme & Exemplar Quotes \\
\hline \multirow[t]{2}{*}{$\begin{array}{l}\text { Economic } \\
\text { Opportunity } \\
(\mathrm{N}=90)\end{array}$} & \multirow{2}{*}{$\begin{array}{l}\text { Themes included poverty, income } \\
\text { inequality, high cost of living, } \\
\text { unemployment, limited job } \\
\text { opportunities, limited high-quality job } \\
\text { opportunities, and struggling economies } \\
\text { locally and regionally. Economic } \\
\text { opportunity was often viewed as } \\
\text { inextricably linked with other factors } \\
\text { such as healthcare, education, and } \\
\text { secure housing. Access to quality, high- } \\
\text { speed internet impacted connectivity } \\
\text { and access to services. }\end{array}$} & $\begin{array}{l}\text { "We don't have a consistent permanent } \\
\text { employment base that keeps our } \\
\text { community growing, competitive, or } \\
\text { sustainable. There is a lack a critical } \\
\text { infrastructure (water, internet, educated } \\
\text { human capital work force) that would } \\
\text { entice industry or business to move } \\
\text { here creating employment growth." [Fire } \\
\text { chief, health and human services] }\end{array}$ \\
\hline & & $\begin{array}{l}\text { "Lack of affordable housing, lack of } \\
\text { high paying jobs, lack of jobs that offer } \\
\text { healthcare and other benefits to } \\
\text { employees, lack of medical providers." } \\
\text { [Economic development coordinator, } \\
\text { community and economic } \\
\text { development] }\end{array}$ \\
\hline \multirow[t]{2}{*}{$\begin{array}{l}\text { Access to Care } \\
(\mathrm{N}=51)\end{array}$} & \multirow{2}{*}{$\begin{array}{l}\text { Leaders described a lack of healthcare } \\
\text { providers and healthcare services within } \\
\text { their communities, particularly as } \\
\text { compounded by rurality. Healthcare } \\
\text { cost, insurance status and coverage, } \\
\text { and distance to health services were } \\
\text { stated as potential challenges to access } \\
\text { to care. A small handful of the } \\
\text { participants mentioned an unequal } \\
\text { distribution of health services in the } \\
\text { communities they serve but did not } \\
\text { further elaborate on why that inequality } \\
\text { may exist. }\end{array}$} & $\begin{array}{l}\text { "The root causes of health inequity in } \\
\text { our area are due to limited rural } \\
\text { supportive of services with access to } \\
\text { care for families/individuals in need. } \\
\text { Often times barriers include education } \\
\text { of services, transportation, and } \\
\text { financial support." [Community impact } \\
\text { director, multisector] }\end{array}$ \\
\hline & & $\begin{array}{l}\text { "Poverty, distances people need to } \\
\text { travel to health practitioners or } \\
\text { facilities. Difficulty to attract health } \\
\text { professionals to the area. Lack of } \\
\text { access to specialized care, i.e. speech } \\
\text { therapists, oncologists. Language } \\
\text { barriers for the Native American elderly, } \\
\text { and many reside in areas without } \\
\text { running water or electricity. High level } \\
\text { of addictions and social problems } \\
\text { exceeds the practitioners and facilities } \\
\text { that can intervene with the care } \\
\text { needed." [Library district director, } \\
\text { multisector] }\end{array}$ \\
\hline
\end{tabular}




\begin{tabular}{|c|c|c|}
\hline Code & Theme & Exemplar Quotes \\
\hline $\begin{array}{l}\text { Social and } \\
\text { Cultural } \\
\text { Cohesion } \\
(\mathrm{N}=34)\end{array}$ & $\begin{array}{l}\text { Included lack of support for mental } \\
\text { health and lack of support systems and } \\
\text { supportive relationships, families, and } \\
\text { homes. Social and cultural cohesion } \\
\text { was linked to or contributed to high } \\
\text { rates of poor mental health, abuse, and } \\
\text { childhood or family trauma, substance } \\
\text { use, and stigma related to substance } \\
\text { use and other health conditions like HIV. } \\
\text { Fewer described topics such as } \\
\text { language barriers and lack of } \\
\text { opportunities to be engaged in the } \\
\text { community. } \\
\text { Both social and physical isolation were } \\
\text { considered a function of rurality and the } \\
\text { unique challenges rural communities } \\
\text { face, including limited services and } \\
\text { resources and lack of connection across } \\
\text { sectors. }\end{array}$ & $\begin{array}{l}\text { "High proportion of low-income jobs. } \\
\text { High proportion of jobs without } \\
\text { benefits. Use of illegal substances } \\
\text { disproportionate to the size of the } \\
\text { population. Children at high risk due to } \\
\text { early traumas and dysfunctional } \\
\text { families. Distance to specialized } \\
\text { medical services." [Superintendent, } \\
\text { education] } \\
\text { "My community has a higher cost of } \\
\text { living with limited job opportunities and } \\
\text { low pay. The youth lack support } \\
\text { services and safe places to go. } \\
\text { Community resources are limited and } \\
\text { mental health resources are lacking." } \\
\text { [Health educator, multisector] }\end{array}$ \\
\hline $\begin{array}{l}\text { Educational } \\
\text { Opportunity } \\
(\mathrm{N}=31)\end{array}$ & $\begin{array}{l}\text { "Lack of education" or just "education" } \\
\text { were commonly listed with no further } \\
\text { explanations. Some of the participants } \\
\text { noted the lack of secondary education } \\
\text { opportunities and support in their } \\
\text { communities. Multiple participants also } \\
\text { mentioned that low education status } \\
\text { and low education standards is } \\
\text { interlinked with the low employment } \\
\text { within their communities. }\end{array}$ & $\begin{array}{l}\text { "A lack of the education necessary to } \\
\text { obtain a long term career." [Regional } \\
\text { director, early childhood development] } \\
\text { "Lack of education, lack of money to } \\
\text { attend school after free public } \\
\text { education, lack of role models, lack of } \\
\text { teamwork / communication for benefits } \\
\text { of community, poor food options at the } \\
\text { local store (soda, chips, candy), } \\
\text { unhealthy lifestyle decisions." } \\
\text { [Superintendent, education] }\end{array}$ \\
\hline $\begin{array}{l}\text { Transportation } \\
(\mathrm{N}=26)\end{array}$ & $\begin{array}{l}\text { A lack of transportation (both personal } \\
\text { and public transportation) was a major } \\
\text { issue in leader's communities. Multiple } \\
\text { participants mentioned distance to } \\
\text { services and rurality being contributing } \\
\text { factors in transportation issues. Some } \\
\text { tied their community's transportation } \\
\text { challenges to issues with the ability to } \\
\text { work, and access to food and health } \\
\text { services. }\end{array}$ & $\begin{array}{l}\text { "Much of our ridership is comprised of } \\
\text { seniors, the disabled, tribal residents } \\
\text { and low income families dependent on } \\
\text { public transit to travel to medical } \\
\text { appointments, the pharmacy and } \\
\text { grocery store and government services. } \\
\text { Public transportation is primary in } \\
\text { alleviating one of the major root causes } \\
\text { of health inequity; without a reliable } \\
\text { mobility service, the health and welfare } \\
\text { of our communities are significantly } \\
\text { impacted." [Grants and transit manager, } \\
\text { transportation] } \\
\text { "Economics and the high cost of living } \\
\text { also many of the residents live out in } \\
\text { the country where transportation is } \\
\text { difficult." [Public defender, law, justice, } \\
\text { and public safety] }\end{array}$ \\
\hline
\end{tabular}




\begin{tabular}{|c|c|c|}
\hline Code & Theme & Exemplar Quotes \\
\hline \multirow[t]{2}{*}{$\begin{array}{l}\text { Housing } \\
(\mathrm{N}=24)\end{array}$} & \multirow[t]{2}{*}{$\begin{array}{l}\text { Included lack of adequate and } \\
\text { affordable housing, both to rent and } \\
\text { buy, limited housing options, and } \\
\text { homelessness in leader's communities. } \\
\text { Housing was often compounded by } \\
\text { other factors, particularly by lack of } \\
\text { economic opportunities. }\end{array}$} & $\begin{array}{l}\text { "We have relatively low unemployment } \\
\text { but do have a lot of low income } \\
\text { citizens. Affordable housing seems to } \\
\text { be a big cause of some of our issues. } \\
\text { People have to pay more towards their } \\
\text { living conditions so takes away from } \\
\text { other issues such as health care. } \\
\text { [Director, health and human services] }\end{array}$ \\
\hline & & $\begin{array}{l}\text { "Lack of affordable housing, transient } \\
\text { population, inability to maintain job } \\
\text { security." [CEO, health and human } \\
\text { services] }\end{array}$ \\
\hline \multirow[t]{2}{*}{$\begin{array}{l}\text { Community } \\
\text { Safety }(N=16)\end{array}$} & \multirow[t]{2}{*}{$\begin{array}{l}\text { Included domestic violence, child abuse, } \\
\text { felony convictions, and substance } \\
\text { (drugs and alcohol) abuse. Participants } \\
\text { also mentioned homelessness, mental } \\
\text { health challenges, and lack of safe } \\
\text { places for youth. }\end{array}$} & $\begin{array}{l}\text { "Mental health challenges (depression, } \\
\text { helplessness, anxiety, stigmas) high } \\
\text { levels of poverty, low levels of } \\
\text { education minimal job opportunity, } \\
\text { somewhat closed off community, high } \\
\text { rates of alcohol, drugs, suicide, STIs, } \\
\text { violence, domestic violence." [Public } \\
\text { health nurse, health and human } \\
\text { services] }\end{array}$ \\
\hline & & $\begin{array}{l}\text { "Homelessness in the community } \\
\text { which relates to economics. Drugs and } \\
\text { alcohol affect families and especially } \\
\text { the children. Number of individuals in } \\
\text { jail. Not enough mental health } \\
\text { providers." [President, multisector] }\end{array}$ \\
\hline \multirow[t]{2}{*}{$\begin{array}{l}\text { Social Justice } \\
(\mathrm{N}=12)\end{array}$} & \multirow{2}{*}{$\begin{array}{l}\text { Themes of incarceration policies and } \\
\text { practices including convictions and the } \\
\text { criminalization of substance use in lieu } \\
\text { of treatment for substance use } \\
\text { disorders; historical and generational } \\
\text { trauma, lack of intergenerational wealth, } \\
\text { land distribution policies that } \\
\text { disproportionately effect Native } \\
\text { Americans; lack of cultural and } \\
\text { community representation in local and } \\
\text { county policy; structural and } \\
\text { institutional racism and discrimination, } \\
\text { including how these are barriers for } \\
\text { policy goals. }\end{array}$} & $\begin{array}{l}\text { "The root causes of health inequity in } \\
\text { the community I serve is the } \\
\text { criminalization of people who use } \\
\text { drugs. There is also institutional } \\
\text { racism, sexism, and other stigma tied to } \\
\text { this. The separation of mental health } \\
\text { disorders from substance use disorders } \\
\text { feeds this as well." [Programs director, } \\
\text { multisector] }\end{array}$ \\
\hline & & $\begin{array}{l}\text { "Wealth inequity and the lack of } \\
\text { generational wealth that sustains } \\
\text { generations. Housing market that } \\
\text { predominantly serves college residents } \\
\text { and the tourism market. Racism and } \\
\text { discrimination remain a significant } \\
\text { problem for all policy goals." [Public } \\
\text { affairs director, policy] }\end{array}$ \\
\hline
\end{tabular}




\begin{tabular}{|c|c|c|}
\hline Code & Theme & Exemplar Quotes \\
\hline \multirow[t]{2}{*}{ Food $(\mathrm{N}=8)$} & \multirow[t]{2}{*}{$\begin{array}{l}\text { When food was highlighted as a } \\
\text { concern in leader's communities, food } \\
\text { deserts, access to nutritious food, food } \\
\text { insecurity, and poor nutrition were } \\
\text { described. Similar to other SDoH, food } \\
\text { systems were often talked about in } \\
\text { synchrony with other factors affecting } \\
\text { the community's overall wellbeing and } \\
\text { health, such as economic opportunities } \\
\text { and transportation. }\end{array}$} & $\begin{array}{l}\text { "We serve the poorest and neediest } \\
\text { senior over } 60 \text { and those under with a } \\
\text { disability. These clients are do not } \\
\text { make enough money on their Social } \\
\text { Security to afford housing, food, and } \\
\text { health. If a client is just } 5 \text { dollars over } \\
\text { the limit for AHCCCS [Arizona Health } \\
\text { Care Cost Containment System, } \\
\text { Arizona's Medicaid program] they can't } \\
\text { afford food." [Client services manager, } \\
\text { health and human services] }\end{array}$ \\
\hline & & $\begin{array}{l}\text { "Low employment opportunities, vast } \\
\text { low-income neighborhoods, diet-related } \\
\text { disease, lack of transportation i.e.: } \\
\text { valley-wide transit line, diminished } \\
\text { access to healthy food with widespread } \\
\text { food desert.". [Executive director, } \\
\text { multisector] }\end{array}$ \\
\hline \multirow[t]{2}{*}{$\begin{array}{l}\text { Environmental } \\
\text { Quality }(N=6)\end{array}$} & \multirow[t]{2}{*}{$\begin{array}{l}\text { Defined as lack of basic and critical } \\
\text { utilities such as lack of running, drinking } \\
\text { or wastewater and electricity. These } \\
\text { were often described in connection with } \\
\text { economic opportunity and living in rural } \\
\text { or tribal lands with limited access to } \\
\text { resources compared to cities and more } \\
\text { urban areas of the region. }\end{array}$} & $\begin{array}{l}\text { "The root causes of health inequity in } \\
\text { our community have to do with access, } \\
\text { many of our community live in very } \\
\text { rural areas that require travel of great } \\
\text { distances to get access to care. There } \\
\text { is also in the same vein a very poor } \\
\text { population that live without even basic } \\
\text { necessities like electricity, running water } \\
\text { and internet service." [County manager, } \\
\text { policy] }\end{array}$ \\
\hline & & $\begin{array}{l}\text { "Agricultural challenges due to heat \& } \\
\text { environment." [Executive director, } \\
\text { multisector] }\end{array}$ \\
\hline \multirow[t]{2}{*}{$\begin{array}{l}\text { Community } \\
\text { Design }(\mathrm{N}=3)\end{array}$} & \multirow{2}{*}{$\begin{array}{l}\text { Community design as a cause of } \\
\text { inequity was defined by lack of } \\
\text { infrastructure, including limited land } \\
\text { development, lack of physical } \\
\text { infrastructure such as streets and } \\
\text { sidewalks, and little interest in } \\
\text { improving or developing infrastructure. } \\
\text { A couple examples described how } \\
\text { insufficient physical infrastructure } \\
\text { affects leader's communities and made } \\
\text { connections between community design } \\
\text { and inequity. }\end{array}$} & $\begin{array}{l}\text { "[My] county is a politically } \\
\text { conservative community and there is } \\
\text { little interest in improving and building } \\
\text { infrastructure needed to address the } \\
\text { environmental inequities } \\
\text { (neighborhoods with paved and } \\
\text { unpaved streets, no sidewalks, etc.)." } \\
\text { [Director, health and human services] }\end{array}$ \\
\hline & & $\begin{array}{l}\text { "Topography, high desert with little } \\
\text { infrastructure. Limited land } \\
\text { development and ownership." } \\
\text { [Economic development manager, } \\
\text { multisector] }\end{array}$ \\
\hline
\end{tabular}

In our analysis, two themes emerged beyond the a priori SDoH, including geographic location and local political context.

\section{Geographic Location ( $\mathrm{N}=27)$}


Given the rurality of the region of northern Arizona of focus, it was no surprise that many leaders identified rurality was a cause of inequity in their community. Participants talked about rural, remote, or isolated areas and a lack of connection as a function of rurality. For instance, rurality was considered to compound a lack of or limited access to various services and resources, such as limited healthcare services often due to long distances to travel to care, lack of affordable housing, with the most affordable housing being in more rural and isolated areas, and unfunded and underperforming schools. A few participants who discussed rurality noted the disparities between rural and urban areas in their communities, observing that rural areas experienced greater challenges compared to urban areas due to limited access to essential social services and goods.

"The disparity between rural and urban areas in the county. Lack of infrastructure: broadband, available land for private use, water, and other support utilities. These conditions negatively affect opportunities for economic development and mobility, and access to health." [Assistant facilities management director, multisector]

"Economic disparity in rural communities across the region, combined with isolation from needed services (social, healthcare). Additionally, rural Arizona's political attitudes of self-reliance, does not provide adequate support for needy populations." [Transit planner, transportation]

\section{Political Context $(\mathrm{N}=10)$}

A number of participants voiced their thoughts on how politics play a role in health inequities. The most common mentioned topics related to politics were about vulnerable and lacking infrastructures, discrepancies between political leaders' decisions and the community's needs, lack of trust and confidence in the government, and unfair tax systems.

"Historic and continued lack of representation at the local and county level being anything other than white, male dominated." [Senior program coordinator, multisector]

"Rural area with low education standards, underfunded and underperforming schools, and lack of economic opportunities. General apathy towards education, along with a desire to live 'off the grid' and away from real or perceived government intervention. Perception that taxes and government interventions are already too high." [Assistant county manager, policy]

\section{Strategies To Address Root Causes Of Health Inequity}

Approximately $63 \%(n=130)$ of participants identified key strategies they considered essential in addressing health inequities in their local communities and in society as a whole. Leaders described strategies that fell into ten broad categories, including 1 ) build community knowledge and capacity; 2 ) develop economic and workforce infrastructure; 3) activate collaboration and partnerships; 4) establish referral and resource systems; 5) provide direct services; 6) ensure flexible, fair, and equitable access; 7) conduct community outreach and engagement; 8) engage in advocacy and policy change; 9) be culturally 
and community responsive; and 10) utilize evidence-based practices (Table 4). Several strategies were oriented towards working directly with the community, such as building community capacity and engaging the community to work together towards something positive. Leaders also described strategies in response to community needs, such as establishing resource systems, directly providing needed services, and making sure access to services is flexible, equitable and culturally relevant. Importantly, participants also discussed strategies for advancing health equity through activating partnerships, using evidence-based practices to make decisions, and promoting health, and engagement in advocacy to effect policy and systems change. [Insert Table 4 below] 
Table 4

Strategies to Address Root Causes of Health Inequity $(n=130)$

Strategies Definition Exemplar Quotes

Build

Community

Knowledge

and Capacity
Providing general education and raising awareness across a range of topics; ensuring appropriate framing and messaging is used when sharing information; supporting and equipping people with tools to be successful

Develop

Economic and Workforce Infrastructure
Developing the local economic and physical infrastructure, including employment opportunities and professional development; expanding existing services; and seeking funding for further development
"Education and awareness building to support people to become their own advocates." [Regional director, multisector]

"Honest education regarding risk/benefits of chosen lifestyles that contribute to long term poor health and poor quality of life."

[Registered nurse, health and human services]

"We have been trying to attract some different types of businesses that could employ people who have little or no secondary education."

[City manager, multisector]

"Economic development efforts, development of regional transit service." [Community development director, community and economic development]

Activate Actively search for opportunities

Collaboration

and

Partnerships to collaborate across

organizations, sectors, and with

community; build partnerships

and capitalize on existing

partnerships; network, share resources, align priorities, and fill gaps to achieve health equity
"Collective community collaborations, sharing of resources among community agencies, looking for avenues to partner with others." [CEO, health and human services]

"Community partnership to tackle infrastructure challenges together versus in silos. Strength is in numbers and joining forces is critical for funding and future enhancements." [Chief information officer, other sector]

"Linking people to community resources is the best strategy I see to help individuals and families address the challenges they face and find support to overcome many of the problems that occur." [Faculty, health and human services]

"The school district provides a full time RN to services our students. She provides referrals as needed." [Superintendent, education]

"Delivery of services which are responsive to these challenges." [Director, health and human services]

"Provide as much food as possible so no one goes hungry." [Soup kitchen supervisor, food systems] 


\begin{tabular}{|c|c|c|}
\hline Strategies & Definition & Exemplar Quotes \\
\hline \multirow{2}{*}{$\begin{array}{l}\text { Ensure } \\
\text { Flexible, Fair, } \\
\text { and } \\
\text { Equitable } \\
\text { Access }\end{array}$} & \multirow{2}{*}{$\begin{array}{l}\text { Provide services and resources to } \\
\text { everybody regardless of financial } \\
\text { or other barriers; ensure resources } \\
\text { and services are free of cost or } \\
\text { low cost and accessible; meet } \\
\text { people where they are by } \\
\text { providing services where they are } \\
\text { needed }\end{array}$} & $\begin{array}{l}\text { "Meeting clients where they are. Coming to } \\
\text { them." [Health educator, food systems] }\end{array}$ \\
\hline & & $\begin{array}{l}\text { "Providing services to all regardless of income } \\
\text { or ability to pay; hiring compassionate, non- } \\
\text { judgmental, knowledgeable service providers." } \\
\text { [Division manager, health and human services] }\end{array}$ \\
\hline \multirow[t]{2}{*}{$\begin{array}{l}\text { Conduct } \\
\text { Community } \\
\text { Outreach and } \\
\text { Engagement }\end{array}$} & \multirow{2}{*}{$\begin{array}{l}\text { Having an active presence in the } \\
\text { community, building rapport and } \\
\text { trust with communities, } \\
\text { conducting outreach via various } \\
\text { communication means to connect } \\
\text { with the community, listening and } \\
\text { responding to the need, and } \\
\text { learning from the community to } \\
\text { work together towards health } \\
\text { equity }\end{array}$} & $\begin{array}{l}\text { "Putting a 'face' to local government--helping } \\
\text { residents see that public servants are not part } \\
\text { of a nameless machine, rather they are friends, } \\
\text { neighbors and live in the same communities." } \\
\text { [Assistant county manager, policy] }\end{array}$ \\
\hline & & $\begin{array}{l}\text { "Work with positive community members that } \\
\text { want to help students, participate in local radio } \\
\text { show in the past to give positive messages, } \\
\text { newsletters, open listening, focus decisions on } \\
\text { what is best for students, try and recruit } \\
\text { positive role models for children." } \\
\text { Superintendent, education] }\end{array}$ \\
\hline \multirow{2}{*}{$\begin{array}{l}\text { Engage in } \\
\text { Advocacy } \\
\text { and Policy } \\
\text { Change }\end{array}$} & \multirow{2}{*}{$\begin{array}{l}\text { Advocating and lobbying for } \\
\text { resources, services, and policy } \\
\text { changes based on community } \\
\text { needs; raising awareness of } \\
\text { issues and influencing decision } \\
\text { makers to advance health equity }\end{array}$} & $\begin{array}{l}\text { "Provider groups banding together to lobby for } \\
\text { change." [CEO, multisector] }\end{array}$ \\
\hline & & $\begin{array}{l}\text { "Advocating for system review/change. Push } \\
\text { for outcomes vs outputs. Asking } 3 \text { questions: } \\
\text { How much did you do, how well did you do it } \\
\text { and is anyone better off?" [Director and chief } \\
\text { health officer, multisector] }\end{array}$ \\
\hline \multirow[t]{2}{*}{$\begin{array}{l}\text { Be Culturally } \\
\text { and } \\
\text { Community } \\
\text { Responsive }\end{array}$} & \multirow[t]{2}{*}{$\begin{array}{l}\text { Recognizing and honoring the } \\
\text { uniqueness of different cultures } \\
\text { and communities; providing } \\
\text { services and resources that are } \\
\text { grounded in the culture and } \\
\text { community }\end{array}$} & $\begin{array}{l}\text { "Our organization tries to bring together } \\
\text { professionals from a range of sectors, help } \\
\text { ensure that prevention strategies are culturally, } \\
\text { linguistically, and age appropriate, and that } \\
\text { they match people's health literacy skills, } \\
\text { provide internet skill-building courses to help } \\
\text { residents find reliable prevention services." } \\
\text { [Executive director, multisector] }\end{array}$ \\
\hline & & $\begin{array}{l}\text { "Acknowledgment of historical trauma and } \\
\text { focus on resiliency building for children and } \\
\text { youth." [Executive director, multisector] }\end{array}$ \\
\hline
\end{tabular}




\begin{tabular}{|c|c|c|}
\hline Strategies & Definition & Exemplar Quotes \\
\hline \multirow[t]{2}{*}{$\begin{array}{l}\text { Utilize } \\
\text { Evidence- } \\
\text { Based } \\
\text { Practices }\end{array}$} & $\begin{array}{l}\text { Staying informed on and } \\
\text { implementing evidence-based } \\
\text { practices into strategies used to } \\
\text { address health equity }\end{array}$ & $\begin{array}{l}\text { "Being informed on evidence-based practices } \\
\text { and incorporating them into our strategies. } \\
\text { Updating policies to prioritize addressing root } \\
\text { causes, rather than how we 'feel' about them." } \\
\text { [Chief probation officer, multisector] }\end{array}$ \\
\hline & & $\begin{array}{l}\text { "Working with community residents and } \\
\text { partners, achieving agreement on proposed } \\
\text { service delivery models, implementing } \\
\text { evidence-based programs, and } \\
\text { monitoring/providing feedback on program } \\
\text { results. When supported, adopt public health } \\
\text { ordinances to promote health (i.e., smoking } \\
\text { ordinances, texting while driving ordinances, } \\
\text { etc.)." [Deputy director, health and human } \\
\text { services] }\end{array}$ \\
\hline
\end{tabular}

\section{Discussion}

The goal of the RHES was to understand multisectoral leaders' perspective and strategies for action on the social determinants of health and the root causes of health inequity in a largely rural, culturally diverse region of northern Arizona. Specially, the RHES assessed knowledge, attitudes, and actions among 206 county-level leaders representing five counties and 13 distinct sectors. We found multisectoral leaders varied in their understanding of the SDoH and the root social, economic and environmental causes of health inequity experienced by their community and were encouraged by the creative community focused strategies to address health inequities locally and regionally.

Although leaders were provided the definition and asked to describe the root causes of inequity, which are defined by elements of interlocking systems of injustice and oppression, the majority of leaders instead provided concrete examples of SDoH. Although an important step in a common language across differing sectors, the SDoH framework does not critically analyze or address the underlying social, economic, and environmental conditions that produce inequities generally and health inequity specifically $(5,22)$. When participants from different sectors were aware of the drivers of health inequity and were especially cognizant of the SDoH facing the communities they serve, they clearly articulated the interplay of complex systems of oppression which place people of color and individuals living in poverty at greater disadvantage and how this disadvantage can lead to adverse health outcomes in their communities. Among these leaders, and despite the variability in how actors from different sectors understand the concept of health inequity, a desire to change the status quo was apparent. Ultimately, our findings suggest that although multisectoral leaders recognize $\mathrm{SDoH}$ and to some extent the root causes of health inequity, and are motivated to collaborate to create positive change, they may not have a common understanding of what health equity is and therefore, how to act to advance health equity through policy, program, and practice goals. While professional differences in training and approach may support the holistic understanding of a topic (i.e., different sectors can leverage their knowledge, skills, and resources 
and tackle the issue from various angles), a shared vision of health inequity would for each sector to be able to leverage their expertise and collaborate meaningfully and effectively.

Our work is consistent with previous work that describes the lack of a universal understanding of health equity $(5,22,23)$, especially when considering perspectives from across disciplines and sectors, participating leaders had differing understandings of the root causes of health inequity. Without a common language for health equity, creating and sustaining multisectoral partnerships as well as guiding policy and resource allocation, while remaining respectful of populations of concerns, can be limited $(14,15,22)$. The root causes of health inequity are diverse, complex, dynamic, and interdependent in nature (17), making clarity and intentionality of utmost importance when pursuing equity efforts that strategically involve various stakeholders with their own agendas (5). Without clear consensus on health equity, stakeholders often struggle to agree on concrete goals and conditions of success potentially contributing to co-opted or wasted resources and efforts and initiatives that lose their focus on health equity $(5,22)$. Having a common language and shared vision for health equity across sectors can contribute to developing multisectoral partnerships and collaboration to influence the SDoH and larger social and economic environment that determine the health and wellbeing of marginalized populations $(12,14,15,22)$.

Furthermore, leaders identified strategies across ten broad areas to address the challenges their communities experience. These suggested strategies indicate leaders are aware of health inequities and their drivers, and they are well-positioned to create and implement community-oriented solutions. Leaders expressed value in community partnerships and multisectoral collaborations to develop and advance health equity initiatives. These responses are supported by the literature and the multiple benefits, including pooling resources, leveraging unique knowledge bases, expanding reach, and avoiding duplication of work a multisectoral collaboration can have (24). Leaders also recognized that multisectoral action can help address health inequity because it recognizes that social and economic factors that influence health often lie outside of the domain of the health sector (25). For example, multisectoral collaborations show promise in developing supportive environments that could enhance access to essential services for marginalized populations (25). Despite challenges to developing successful multisectoral collaborations, recent research by Narain et al. (15) has shown that framing health equity issues in ways that resonated with sectors outside of public health was valuable for promoting work across sectors to improve health equity. This includes, for example, using more inclusive language that is understood across sectors, aligning priorities including missions and operational costs, and creating a shared vision with partners and community stakeholders. Furthermore, highlighting how health equity goals advance the missions of sectors outside of health services and public health helps foster support for health equity in these other sectors and develop more effective collaborations (15). This finding further supports the need for common lexicon and shared values in creating and sustaining multisectoral collaborations determined to address health equity.

\section{Implications for Public Health Practice and Research}


Our findings indicate that multisectoral leaders in northern Arizona recognize SDoH in the communities they serve. However, recognition alone is insufficient to improve conditions of health equity. The next step is action, embracing a multisectoral approach to engage broad stakeholders, including private, public, and grassroots organizations and community members in addressing health inequities. Leaders can look at existing efforts and use creativity and innovation to engage community and multisectoral stakeholders in building equity solutions together. The Bay Area Regional Health Inequities Initiative is an example of effective cross-sectional work with 10-member health departments and over 200 community partners collaborating to drive programmatic, systems, and policy change that enables healthy communities and economic prosperity for all in the California Bay Area (26).

Similarly, prior to action, there is a need for shared language, and practice on the concept of health equity. Previous research highlights the importance of a common language in conducting health equity work as well as developing and maintaining partnerships across sectors to solve inequity issues together $(14,15$, 22). The advancement of health equity and the elimination of social-structural inequities also require the engagement of critical epistemology and praxis that decentralize health research and institutions as the only routes to achieve health equity (27). Historically oppressed communities, policymakers, stakeholders and public health researchers are the frontlines in ensuring that the crucial elements of health equity are understood in public and private sectors (22), and thus, should set the stage for a common language when engaging in multisectoral work. This could be achieved, for instance, by including a clear definition with essential values of health equity in state health improvement plans. Finally, the COVID-19 pandemic has shown a spotlight on longstanding inequities globally and in the US with its disparate impact on marginalized communities. Health equity frameworks and multisectoral approaches will be essential in alleviating the impacts of the pandemic on the SDoH for already vulnerable populations, saving lives, and advancing health equity overall $(28,29)$.

As a participant in the NIH Research Center in Minority Institution (RCMI) Program which aims to "develop and strengthen the research infrastructure necessary to conduct state-of-the-art biomedical research and foster the next generation of researchers from underrepresented populations" our Southwest Health Equity Research Collaborative (SHERC) leveraged the RHES to inform the focus of our Center's community engagement and investment in research infrastructure. By engaging multisectoral leaders across our region, we as a university partner are now in a better position to understand from a social determinant of health and health equity frame the community identified research issues and solutions that our Center could mobilize to address as a regional research partner. As an RCMI, we have taken intentional steps to structure our internal research grant opportunities to support the strategies to address the root causes of health equity outlined in Table 4 . Through our community engagement, research infrastructure and investigator development cores have also outlined several intentional steps to reflect community need in our research training, technology, and targeted funding initiatives. These steps will ensure we are growing a research infrastructure that aligns with the 'on the ground' issues facing multisectoral leaders in our region and leverages the full interdisciplinary and team science approach required to solve complex public health problems of this century. 


\section{Limitations and Strengths}

Based on standard procedures used in qualitative research studies, purposive sampling methods were used to recruit multisectoral leaders from northern Arizona region $(30,31)$. While purposive sampling methods are highly vulnerable to selection bias and sampling error, recent research has shown that these methods are more efficient and result in more 'information-rich' cases for qualitative inquiry $(32,33)$.

Data adequacy in qualitative research is determined by both the appropriateness of sample size and sample composition (34). Using a community-engaged approach to recruit participants for the RHES ensured that respondents were recognized as sector leaders in their community. While we successfully obtained representation from all 13 sectors, $95 \%$ of all participants identified with either health and human services (49\%), education (26\%), or community and economic development $(20 \%)$. This imbalance in sample composition is likely due to individuals who identified with more than one sector, as is often the case in less populated counties where individuals may be responsible for leading more than one department. We also acknowledge the lack of racial and ethnic diversity in our respondents. Still, we are uncertain if this is a limitation of our recruitment strategy or a true reflection of the lack of diversity of leadership in northern Arizona.

With a completion rate above $60 \%$ and participation across all sectors and counties of interest, including many sectors not typically included in equity work, we are confident that the outcomes of the RHES capture of the perspectives of multisectoral leadership in the northern Arizona region. This research was completed prior to the COVID-19 pandemic, which has potentially created more awareness about health equity for those in sectors outside of the health or public health sectors. Additional assessment post COVID-19 of health equity among multi-sectoral representatives is necessary.

\section{Conclusions}

Numerous health inequities and their drivers were identified by community leaders from different sectors in the northern Arizona region. Discrimination and disproportionate allocation of power and resources were listed as common root causes of health inequity. Many of the respondents also recognized the link between the $\mathrm{SDoH}$ and the existing health inequities. A majority of responses (75\%) were categorized as SDoH across sectors, where leaders often described complex synergies between the various factors and systems impacting the communities they serve. Community leaders in the northern Arizona region acknowledge the importance of multisectoral partnerships and collaborations in improving health equity for their communities but a common understanding of health inequities remains to be widely established and is essential for conducting effective multisectoral work. This baseline assessment will serve as the basis for a productive dialogue about the various and unique contributions that each sector can activate to influence and strengthen health equity in our region.

\section{Abbreviations}


CAC

community advisory council

CEC

community engagement core

BARHII

Bay Area Regional Health Inequities Initiative's

RCMI

Research Centers in Minority Institution

RHES

Regional Health Equity Survey

SDoH

social determinants of health

SHERC

Southwest Health Equity Research Collaborative

\section{Declarations}

Ethics approval and consent to participate: The development and implementation of the Regional Health Equity Survey was reviewed and deemed nonhuman subjects research by the Northern Arizona University Institutional Review Board (Project number: 1198096-1).

Consent for publication: Not applicable.

Availability of data and material: The datasets generated during and/or analyzed during the current study are not publicly available but are available from the corresponding author on reasonable request.

Competing interests: The authors declare that they have no competing interests.

Funding: This work was financially supported by the National Institutes of Health (grant 1U54MD012388).

Authors' contributions:

Study concept and design: S.S., D.J.J., M.R., A.E.S.L., H.J.W., C.C., N.I.T.-S.

Analysis and interpretation of data: D.J.J., M.S., S.S., M.R.

Drafting of the manuscript: D.J.J, S.S., M.R., M.S.

Critical revision of the manuscript for important intellectual content: D.J.J., S.S., M.R., M.S., A.E.S.L., H.J.W., C.C., N.I.T.-S.

Obtained funding: S.S., N.I.T.-S. 
All authors have read and approved the final manuscript.

Acknowledgements: Numerous people made significant contributions to the development and implementation of the work documented in this paper. In particular, the authors would like to thank the following members of our Community Advisory Council: Amanda Guay, Emma Torres, Chelsey Donohoo, Emily Davalos, Candida Hunter, Stephen Julian, Mare Schumacher, Joyce Hamilton, Diana Gomez, Eric Wolverton, and Shepard Tsosie.

\section{References}

1. Feachem RG. Poverty and inequity: a proper focus for the new century. Bull World Health Organ. 2000;78(1):1-2.

2. Centers for Disease Control and Prevention. Healthy People 2010. https://www.cdc.gov/nchs/healthy_people/hp2010.htm (2015). Accessed 1 Sept 2020.

3. National Academies of Sciences $E$, and Medicine. Communities in action: pathways to health equity. Baciu A, Negussie Y, Geller A, Weinstein JN, editors. Washington (DC): The National Academies Press; 2017.

4. Braveman P. What are health disparities and health equity? We need to be clear. Public Health Rep. 2014;129(Suppl 2):5-8.

5. Braveman P, Arkin E, Orleans T, Proctor D. A P. What is health equity? And what difference does a definition make? Princeton, NJ; 2017.

6. Salunke S, Lal DK. Multisectoral approach for promoting public health. Indian J Public Health. 2017;61(3):163-8.

7. Alexander JA, Christianson JB, Hearld LR, Hurley R, Scanlon DP. Challenges of capacity building in multisector community health alliances. Health Educ Behav. 2010;37(5):645-64.

8. Bromley E, Figueroa C, Castillo EG, Kadkhoda F, Chung B, Miranda J, et al. Community partnering for behavioral health equity: public agency and community leaders' views of its promise and challenge. Ethn Dis. 2018;28(Suppl 2):397-406.

9. Pies C, Barr M, Strouse C, Kotelchuck M, Best Babies Zone Initiative T. Growing a best babies zone: lessons learned from the pilot phase of a multi-sector, place-based initiative to reduce infant mortality. Matern Child Health J. 2016;20(5):968-73.

10. Siegel B, Erickson J, Milstein B, Pritchard KE. Multisector partnerships need further development to fulfill aspirations for transforming regional health and well-being. Health Aff. 2018;37(1):30-7.

11. Gopalan SS, Mohanty S, Das A. Challenges and opportunities for policy decisions to address health equity in developing health systems: case study of the policy processes in the Indian state of Orissa. Int J Equity Health. 2011;10:55.

12. Ndumbe-Eyoh $\mathrm{S}$, Moffatt $\mathrm{H}$. Intersectoral action for health equity: a rapid systematic review. BMC Public Health. 2013;13:1056. 
13. Storm I, den Hertog F, van Oers $H$, Schuit AJ. How to improve collaboration between the public health sector and other policy sectors to reduce health inequalities? A study in sixteen municipalities in the Netherlands. Int J Equity Health. 2016;15:97.

14. Henson RM, McGinty M, Juliano C, Purtle J. Big city health officials' conceptualizations of health equity. J Public Health Manag Pract. 2019;25(4):332-41.

15. Narain KDC, Zimmerman FJ, Richards J, Fielding JE, Cole BL, Teutsch SM, et al. Making strides toward health equity: the experiences of public health departments. J Public Health Manag Pract. 2019;25(4):342-7.

16. Lavizzo-Mourey R. How to build a culture of health. QJM. 2017;110(2):59-60.

17. Remiker M, Sabo S, Jiménez D, Samarron Longorio A, Chief C, Williamson H, et al. Using a multisectoral approach to advance health equity in rural Arizona: community-engaged survey development and implementation study. JMIR Form Res. 2021;5(5):e25577.

18. Northern Arizona University, Center for Health Equity Research. Advanced wellbeing in northern Arizona: a regional health equity assessment. 2017.

19. The Bay Area Regional Health Inequity Initiative. Local health department organizational selfassessment for addressing health inequities. 2010.

20. Vitalyst Health Foundation. Vitalyst health. http://vitalysthealth.org/wpcontent/uploads/2017/09/EOHC-Handout-Jan2018.pdf (2018). Accessed 22 Oct 2020.

21. O'Connor $\mathrm{C}$, Joffe $\mathrm{H}$. Intercoder reliability in qualitative research: debates and practical guidelines. Int J Qual Methods. 2020;19:1609406919899220.

22. Braveman P, Arkin E, Orleans T, Proctor D, Acker J, Plough A. What is health equity? Behav Sci Policy. 2018;4(1):10-4.

23. Pauly BM, Shahram SZ, Dang PTH, Marcellus L, MacDonald M. Health equity talk: understandings of health equity among health leaders. AIMS Public Health. 2017;4(5):490-512.

24. Rudolph L, Caplan J, Ben-Moshe K, Dillon L. Health in all policies: a guide for state and local governments. Washington, DC and Oakland, CA American Public Health Association and Public Health Institute; 2013.

25. Sampson UKA, Kaplan RM, Cooper RS, Diez Roux AV, Marks JS, Engelgau MM, et al. Reducing health inequities in the U.S.: recommendations from the NHLBI's health inequities think tank meeting. J Am Coll Cardiol. 2016;68(5):517-24.

26. Bay Area Regional Health Inequities Initiative. https://www.barhii.org/ (2020). Accessed 15 Aug 2021.

27. Bowleg L. Towards a critical health equity research stance: why epistemology and methodology matter more than qualitative methods. Health Educ Behav. 2017;44(5):677-84.

28. Okonkwo NE, Aguwa UT, Jang M, Barre IA, Page KR, Sullivan PS, et al. COVID-19 and the US response: accelerating health inequities. BMJ Evid Based Med. 2020. 
29. Walter-McCabe HA. Coronavirus health inequities in the United States highlight need for continued community development efforts. The International Journal of Community Social Development. 2020;2(2):211-33.

30. Luborsky MR, Rubinstein RL. Sampling in qualitative research: rationale, issues, and methods. Res Aging. 1995;17(1):89-113.

31. Marshall MN. Sampling for qualitative research. Fam Pract. 1996;13(6):522-5.

32. van Rijnsoever FJ. (I can't get no) saturation: a simulation and guidelines for sample sizes in qualitative research. PLoS One. 2017;12(7):e0181689.

33. Patton MQ. Qualitative evaluation and research methods. 2nd ed. Newbury Park: Sage Publications; 1990. $532 \mathrm{p}$.

34. Vasileiou K, Barnett J, Thorpe S, Young T. Characterising and justifying sample size sufficiency in interview-based studies: systematic analysis of qualitative health research over a 15-year period. BMC Med Res Methodol. 2018;18(1):148.

\section{Figures}




\section{Sector Representation ( $\mathbf{N}=\mathbf{2 0 1})$}

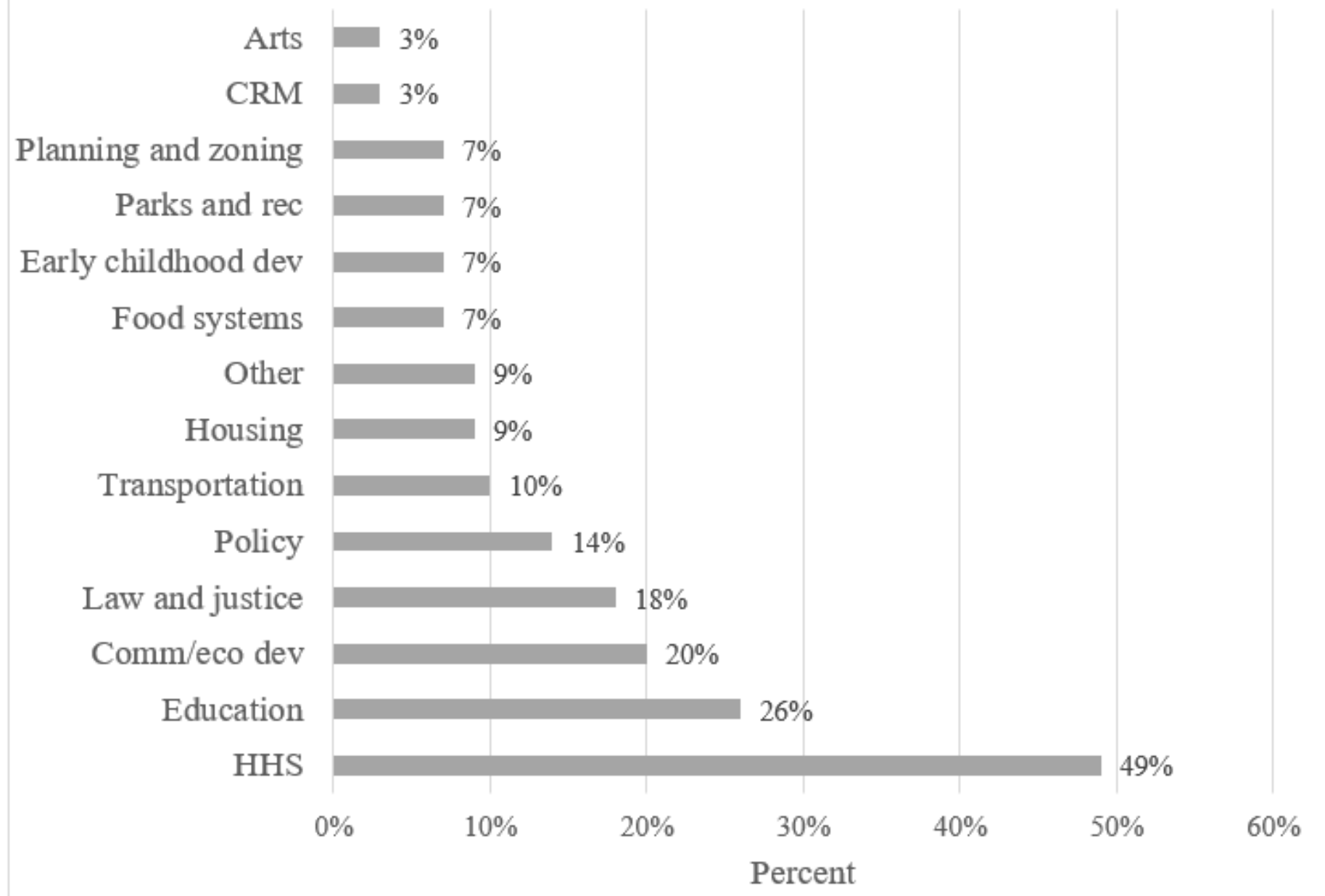

\section{Figure 1}

Sector Representation. Note: Sector respondents were allowed to check all that apply, "CRM" = Cultural Resource Management, "HHS" = Health and human services, "Comm./eco dev" = Community and Economic Development. 


\section{How uneven is the distribution of these resources and services in the community you serve?}

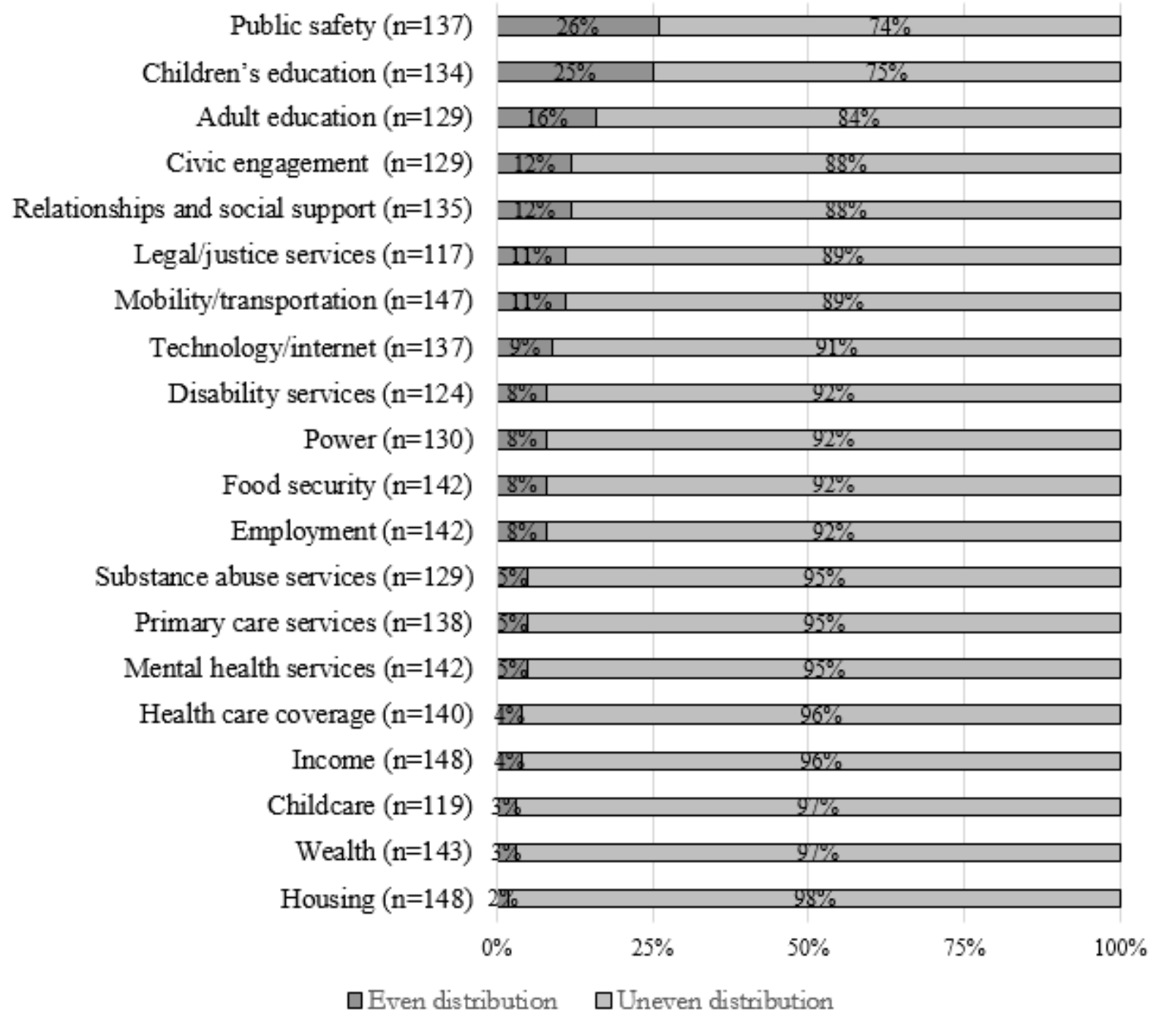

\section{Figure 2}

Perceived Distribution of Community Resources. Note: "Uneven distribution" includes responses to both "Very uneven" and "Somewhat uneven." 